\title{
NPO Funding in Italy: The Role and the Contribution of Corporate Governance
}

\author{
Patrizia Gazzola ${ }^{1}$, Stefano Amelio ${ }^{2}$, Daniele Grechi ${ }^{3} \&$ Fragkoulis Papagiannis $^{4}$ \\ ${ }^{1}$ Department of Economics, University of Insubria, Varese, Italy \\ ${ }^{2}$ Department of Business Administration and Law, University of Milano-Bicocca, Milano, Italy \\ ${ }^{3}$ Department of Human Sciences and Territorial Innovation, University of Insubria, Como, Italy \\ ${ }^{4}$ Faculty of Business and Law, Liverpool John Moores University, Liverpool, UK \\ Correspondence: Patrizia Gazzola, Department of Economics, University of Insubria, 21100, Varese, Italy. \\ E-mail: patrizia.gazzola@uninsubria.it
}

Received: October 1, 2020

doi:10.5539/ijbm.v15n12p1
Accepted: November 3, 2020

Online Published: November 6, 2020

\begin{abstract}
By adopting mainly the "principal-agent theory", the study analyses how non-profit organizations (NPOs) corporate governance structure could increase the trust of the donors and therefore affect their ability to receive donations from taxpayers. Starting from a literature review we concentrated our attention on the non-profit sector where NGOs represent the largest category. In Italy, starting from 2006, all NPOs could receive funding deriving from taxes paid by citizens when making tax returns with the so called ' 5 per thousand' of the personal income tax. We analyzed the corporate governance disclosure practices of the first Italian 100 NPOs that received the highest donations from 5 per thousand. In particular, we elaborated a CGI index that includes governance and informativeness. This paper shows how an efficient and transparent corporate governance structure motivates the donors to donate 5 per thousand to NPOs that demonstrate good corporate governance. The findings suggest that taxpayers are inclined to allocate 5 per thousand to organizations where the information level, from a governance point of view, is high, easily available and clear about the purpose in the specified field of research.
\end{abstract}

Keywords: 5 per thousand, Corporate governance, Non-profit organizations, NPO funding, Social impact

\section{Introduction}

The "third sector" in Italy has an annual turnover that exceeds 60 billion euros per year and includes all non-profit organizations (NPOs), of which non-governmental organizations (NGOs) represent the most numerous category (Gazzola et al., 2019a). NPOs represent an important pillar in advanced economic systems as they carry out a significant economic activity (Gazzola, Ratti \& Amelio, 2017; Gazzola \& Amelio, 2015; Peng, 2019). The term non-profit does not mean profit absence, but profit distribution among stakeholders is prohibited (Salamon \& Anheier, 1997). NPOs exist for the following three prominent reasons: i) They act efficiently and effectively as private producers of particular public goods, substituting state services; ii) They cover informational and organizational gaps of public information asymmetries; iii) They are operating under a discrete and favorable regulatory status. An important and common NPO aspect is the collection of contributions, donations and concessions, which guarantee their business survival. In Italy, the presence of NPOs reduces direct intervention of the state. Therefore, they receive concessions compensating the costs that the State would otherwise have to bear directly (Airoldi, Brunetti \& Coda, 2005). As a result, NGO funding has grown considerably since the 1980s (Moore \& Stewart, 1998).

In 1985, Italy introduced for the first time a financing mechanism (intended to finance certain categories of NPOs), consisting of a percentage designation of the taxes declared by taxpayers. This designation tax is identified as the "8 per thousand". Subsequently, this system is introduced in other countries (Hungary in 1996, Slovak Republic in 1999, Lithuania in 2002, Romania and Poland in 2003 (Radinger, 2017). Since 2006 (with Law no. 266 of 23 December 2005, article 1, paragraphs 337 and subsequent ones), all NPOs can receive funding from citizens. In fact, citizens can decide, when making tax return, to voluntarily donate a sum ("5 per thousand" or " $5 * 1000$ ") to organizations and entities that meet certain requirements. This sum is equal to $5 * 1000$ of the personal income tax to purposes of social interest within the tax declaration they draw up (and 
submit to the tax authorities) annually. In this declaration, they have three possibilities. The first possibility is to allocate 5 per thousand to one of the generic categories, as highlighted below, by signing the corresponding taxform box. The second possibility is not to allocate 5 per thousand to any institution. In this case, the payment of 5 per thousand is cancelled and remains in the coffers of the State. The third and final possibility is to allocate 5 per thousand to a specific non-profit organization by signing in the corresponding tax-form box the institutional tax code. In this sense, the second option represents "scelte generiche" (generic choices) while the third option "scelte espresse" (effective choices). Finally, the choice to donate 5 per thousand is voluntary and may depend on different elements, such as the presence of sustainability reporting practices. In recent years, the Italian non-profit sector has undergone a period of important changes. With a series of rules, the so-called "Third Sector Reform" was carried out. In particular, Legislative Decree 117/2017, updated with Legislative Decree 18/2020, introduced the Third Sector Code, establishing the "single national Register of the Third Sector". The 5 per thousand regulation was renewed with Legislative Decree 111/2017 as part of the Third Sector Reform, but, in fact, the provisions contained therein are not yet applicable due to the lack of implementing decrees. Following the reform, only the organizations present in the register will be able to access the 5 per thousand contributions.

According to Gazzola et al. (2019a), sustainability reporting and disclosure practices carry a number of financial and social advantages, including the creation of trust by donors towards an identified NGO. According to Gandía (2008), the issue of corporate governance is of fundamental importance. It indicates that an investor could be confident and trustful on managerial practices and boards of directors' decisions. In fact, the worldwide proliferation of corporate governance codes is a valuable demonstration of such an approach. In addition, corporate governance influences the performance of NPOs, including therefore their ability to acquire financial resources (Hasnan et al., 2016; Hideto Dato, Hudon \& Mersland, 2020; Bellante et al., 2018). To attract donors, good governance practices must then be disclosed (Banding \& Mayangsari, 2017; Chokkalingam, 2017; Yeo, Chong \& Carter, 2017). This study then presents contribution for governance disclosure NPO literature. Given the above assumptions, this research aims to analyze the relationship between the amount of 5 per thousand received by the NPOs and their corporate governance (GC) structure. It aims to highlight if the existence of a good corporate governance structure could increase the trust of the donors (considered to be investors) towards an NPO. The research focuses on the Italian context in which this particular financing mechanism linked to the payment of taxes by taxpayers is present. The results can be generalized to all those contexts in which national legislation provides for this possibility.

\section{Literature Review and Framework}

A plethora of topical studies, contemplate that a good corporate governance could have a series of different, but positive, effects on any company (Randøy \& Nielsen, 2002; Lo et al., 2010; Chen et al., 2009; Bhagat and Bolton, 2008; Denis \& McConnell, 2003; Denis et al., 1997; Ahn \& Walker, 2007; Netter et al., 2009; Bauguess et al., 2009; Brav et al., 2005; Chidambaran \& Prabhala, 2003; Chung et al., 2002; Park \& Shin, 2004; Berkman et al., 2009; Chen et al., 2006; Chakraborty, Gao and Sheikh, 2019). The importance of the corporate governance is also demonstrated by the presence of contributions in the accounting, economics, finance and management sectors (Bhagat \& Black, 2002; Gandía, 2008; Shleifer \& Vishny, 1997; Turley \& Zaman, 2004). Corporate governance is a topic aligned with the for-profit sector and only in recently it extends to the non-profit one (Eldenburg et al. 2001; Speckbacher, 2008; Ostrower \& Stone, 2006). According to Shleifer and Vishny (1997), "Corporate governance deals with the ways in which suppliers of finance to corporations assure themselves of getting a return on their investment". In addition, Tirole (2001) considers that "Corporate governance [is] the design of institutions that induce or force management to internalize the welfare of stakeholders". While, according to Anheier, 2005 "Corporate governance is the system by which organizations are directed and controlled. The corporate governance structure specifies the distribution of rights and responsibilities among different participants in the corporation, such as the board, managers, shareholders, and other stakeholders, and spells out the rules and procedures for making decisions on corporate affairs. By doing this, it also provides the structure through which the company objectives are set and the means of attaining those objectives and monitoring performance". As Jegers (2009) points out, most economic approaches related to corporate governance consider the goal of profit maximization as the objective of the company. Therefore, these topical theories are examining how the managerial actions together with corporate governance could lead to profit maximization. As a result, NPOs could follow some of these economic theories, which are typical of for-profit organizations. Although, in the non-profit sector they could be applied for profit creation, but not for profit distribution (Steinberg, 2003).

According to the "principal-agent theory" (Jensen \& Meckling, 1976; Bendickson et al., 2016), the relationship between the principal and the agent is characterized by agency costs (e.g., monitoring costs, bonding costs and 
residual loss). This because there is a "contract under which one or more persons (the principal(s)) engage another person (the agent) to perform some service on their behalf which involves delegating some decision-making authority to the agent. If both parties to the relationship are [individual welfare] maximizers there is good reason to believe that the agent will not always act in the best interests of the principal". Therefore, this problematic presence of informational asymmetries, between the principal and the agent, could also be found in the relationship between donors and donation recipients. In general, these informational asymmetries are traceable between the various categories of stakeholders (principal) and the NPO (agent). In these cases (Freeman, 1984), the notion of principal is broader than previously defined on the theory of agency which restricts the group of principals to only shareholders. The actors involved in an NPO are in fact multiple and the roles they play are different (Herlin \& Pazirandeh, 2012; Bernstein, Buse \& Slatten, 2015). As a result, this framework could be adopted in a non-profit organization (Hewitt \& Brown, 2000; Miller-Millesen, 2003). The incomplete contracts (bargaining) theory (Williamson, 1985; Grossman \& Hart, 1986; Hart \& Moore, 1990; Shapira, 2000; Van den Berg, 2004) could better clarify the need for a good corporate governance structure within an NPO. In NPOs, various categories of stakeholders invest something (e.g., money, time, etc.) into the relationship and expect to get something in return for their investment. However, a communication gap could be present as contracts are incomplete under this perspective because the return (e.g., satisfaction, money, etc.) is not usually specified in advance.

Likewise, the 5 per thousand donation represents an investment, but the resulting relationship is not contractually stated. Consequently, the designation tax has no enforceable contracts that specify the return on investment or the intended use of the investment, but a choice on the tax declaration. This relationship between donors and an NPO is a good example of an incomplete contract. As corporate governance attempts to minimize the inefficiencies resulting from incomplete bargaining, as not all donors can participate in the NPO board, it is proper to safeguard them with an efficient corporate governance structure.

This paper aims to realize if an efficient and a transparent corporate governance generates greater trust to the donors and consequently motivates the donors to donate 5 per thousand to NPOs that demonstrate good corporate governance. Therefore, we analyze the corporate governance disclosure practices of the first 100 NPOs that received the highest donations from ' 5 per thousand', using information from their websites or other data available on the internet. Consequently, we formulate the following two hypotheses:

H1: Italian taxpayers decide to donate 5 per thousand to subjects who operate in sectors of recognized public interest, but without identifying a specific organization ("generic choice").

This first hypothesis assumes that the distribution of the sums collected is not related to the knowledge of the corporate governance variables of the organizations. Thus, the generic choices are selected without the consideration of the information mechanisms of the corporate governance (CG) process.

H2: Italian taxpayers decide to donate 5 per thousand to subjects who operate in sectors of recognized public interest, identifying a specific organization ("effective choices").

This second hypothesis assumes that taxpayers make this choice considering the corporate governance variables of the organizations. In order to analyze the existence of a statistical relationship between corporate governance and the 5 per thousand received, the main variables that describe corporate governance of NPOs have been identified through a literature review. In particular, literature domains relating to the board size, as discussed by Chan et al., 2013; Choi et al., 2013; Moscariello, 2012; Nekhili and Cherif, 2009. On the one hand, Marchini, et al. (2018) favoring the large board of directors' variable relating it positively with CG quality. On the other hand, Chan et al., 2013; Hu et al., 2012; Liu and Lu, 2007; Lo et al., 2010; Moscariello, 2012 are in favor of the role duality within the board of directors (e.g., 1 if the CEO is also the Chairperson, 0 otherwise). As a result, they assume a negative association between small board size and CG quality. Likewise, Hess and Auman, (2001), Sundaram and Yermack, (2007) contemplate the age variable, supporting that it has a positive association with CG quality. In addition, Barua et al. (2010) introduce that the gender variable has a positive association with CG quality. Finally, all other variables considered derive from the legislation governing analysis of the third sector in Italy. They include the presence of mandatory or facultative bodies that these organizations could adopt.

\section{Methodology}

According to the literature review, the role of corporate governance and the $5 * 1000$ amount received by NPO industries is relevant to various motivations. It is important to examine and verify if the NPOs that received the amounts have a relation with some variables, primary or secondary, or if there is not an association between them. To analyze this information and these hypotheses we have selected a sample of Italian NPOs with a set of financial, economic, social and corporate governance data, as well as prominent indicators to carry out an 
efficient descriptive statistics and an econometric analysis. Based on the official data of the Italian revenue agency, we selected a sample of the top 100 Italian NPOs that received, in 2016, the highest amounts of $5 * 1000$. In fact, 2016 represents a critical year, preceding the implementation of the aforementioned Third Sector Reform. Within this sample, it is possible to identify heterogeneous realities, because there is a large number of NPOs with several diverse business goals. As a result, we categorize and create some functional subcategories. This further functional categorization enables us to improve the quality of our results. Therefore, the subcategories are the following: i) Volunteering: This category entails a multiplicity of associations related to the environment and social assistance. An indicative sample includes abandoned children, terminally ill, assistance for elder people; ii) Scientific Research: in this category there are universities and certified scientific research institutes; iii) ASD: amateur sports clubs, including a wide variety of sporting organizations; iv) Health Research: In this category there are health foundations and health research institutes; and v) Italian municipalities.

The following table (Table 1) describes this classification, which is not coherent because an NPO could be a multipurpose institute. For example, medical research institutes are classified simultaneously as scientific and health research institutes. As a result, the sample, after this classification, is composed of:

Table 1. NPO classification

\begin{tabular}{llllll}
\hline Volunteering & $\begin{array}{l}\text { Amateur sport } \\
\text { association }\end{array}$ & Scientific Research & Health Research & Municipalities & Multi-Purpose (Note 1) \\
\hline 73 & 0 & 28 & 21 & 0 & 18 \\
\hline
\end{tabular}

From a geographical point of view, the following graph represents the origin of these 100NPOs subdivided per Italian regions.

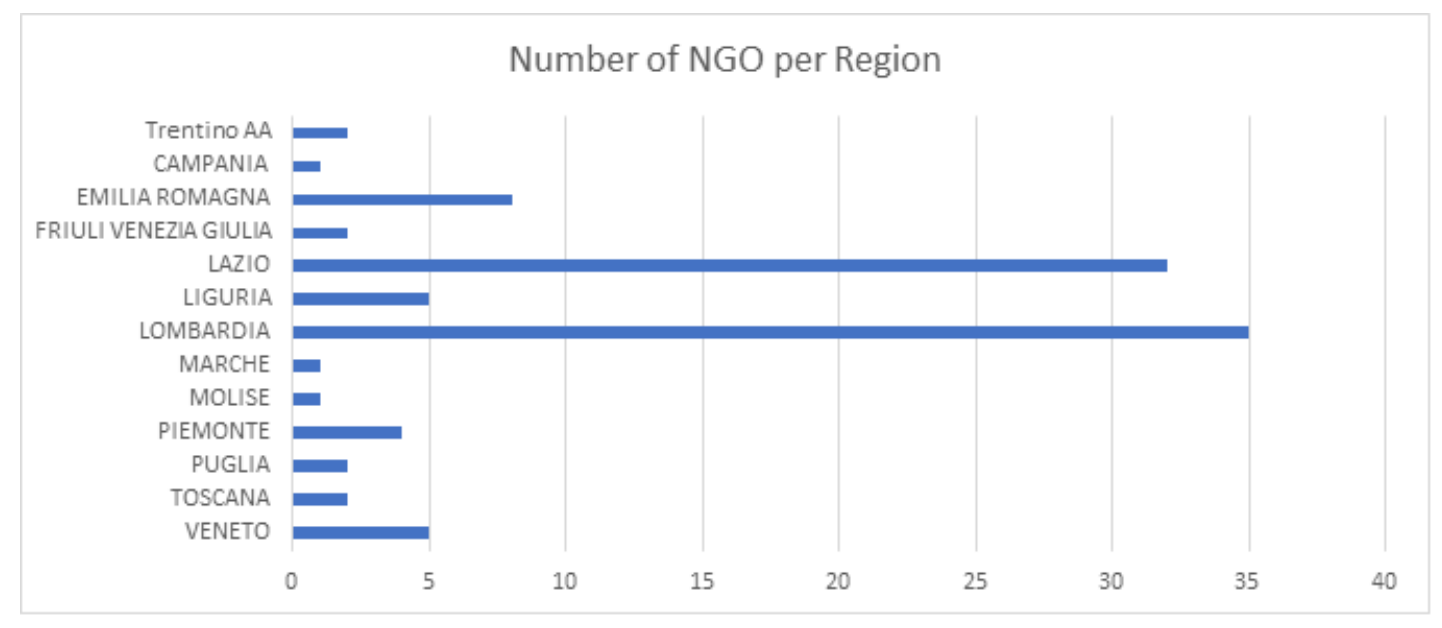

Figure 1. NPO distribution

In thirteen Italian regions, out of 20, there is at least one of these 100 entities. Lombardy ranks first with 35 and follows Lazio with 32. The main evidence, deriving from the previous graph, is that there is not a uniform distribution between the Italian regions. For this motivation the Gini index (Paruolo, 1999) is equal to 0.79 and shows a high concentration in some regions respect to others. The motivation is certainly to be found in the Italian regional differences, in fact it is known that inequalities, especially in the field of scientific research, are relevant among Italian territories (Murro \& Peruzzi, 2018; Castellani et al., 2010).

Into the following tables 2 and 3 there are the variables used for this analysis. These elements are retrieved from three main sources. In fact, the NPO list is obtained from the revenue agency and consequently we select the top 100 in Italy. The other data relating to corporate governance and CSR are manually retrieved from companies' websites and the social reports of the involved companies.

The variables used for the analysis were found manually and automatically through different sources. First of all, the website of each NPO was analyzed and it was possible to extract all of the official available documents. With 
this first phase we were able to obtain information relating to the company, its governance and control bodies (such as the board of directors, the number of members and the arbiters board and the auditors board). The information referred to the expressed choices and to the generic choices was derived from the financial statements, from the social reports using the Aida database. The database contains financial, personal and commercial information on more than one million Italian joint stock companies. For each of them this database offers the detailed balance sheet according to the complete scheme of the IV EEC directive, the complete data sheet with a description of the activity carried out, shareholders, shareholdings, board of directors with a time horizon of 10 years (Bureau Van Dijk, 2012).

On table 2 and 3 there are the entire set of considered variables We have decided to separate the variables in two tables to have the numercal variable on tables 2 and the binary variables on table 3 .

Table 2. Numerical variables

\begin{tabular}{|c|c|}
\hline Variables Name & Description of the variable \\
\hline Arbiters Board & If this body is explicit, it represents the number of members \\
\hline Auditors Board & If this body is explicit, it represents the number of members \\
\hline Board of Directors size & If this body is explicit, it represents the number of members \\
\hline CGI INDEX & $\begin{array}{l}\text { This index represents the level of Corporate Governance information considering the following Variables: SOCIAL } \\
\text { BALANCE 2016, CORPORATE GOVERNANCE Social balance and CORPORATE GOVERNANCE on the } \\
\text { Website }\end{array}$ \\
\hline Choice number & Number of choices related to an NPO \\
\hline Executive_Committee & If this body is explicit, it represents the number of members of the executive committee \\
\hline $\begin{array}{l}\text { Expressed } \quad \text { Choices } \\
\text { Amount }\end{array}$ & This variable represents the effective amount of the Direct/Expressed Choices (Independent variable) \\
\hline Female (F) & Number of females in the board of directors \\
\hline $\begin{array}{l}\text { Generic } \\
\text { Amount }\end{array}$ & This variable represents the effective amount of the Generic Choices (Independent variable) \\
\hline Male (M) & Number of male in the board of directors \\
\hline Members Board & If this body is explicit, it represents the number of the assembly members \\
\hline Total choiche Amount & Total Amount of $€$ per NPO (Independent variable) \\
\hline
\end{tabular}

Table 3. Bernoullian variables

\begin{tabular}{|c|c|}
\hline Variables & Description of the variable \\
\hline Age of the Board & This variable assumes value 1 if the age of board of the NPO is explicit \\
\hline $\begin{array}{l}\text { Corporate Governance } \\
\text { Balance }\end{array}$ & $\begin{array}{l}\text { This variable assumes value } 1 \text { if the NPO has the CORPORATE GOVERNANCE within the social } \\
\text { balance }\end{array}$ \\
\hline $\begin{array}{l}\text { Corporate Governance and CSR } \\
\text { Website }\end{array}$ & $\begin{array}{l}\text { This is a dummy variable that is equal to } 1 \text { if the information about CG and CSR are available on the } \\
\text { website }\end{array}$ \\
\hline Duality & $\begin{array}{l}\text { This is a dummy variable that is equal to } 1 \text { if the chairman of the board is also the CEO of the company } \\
\text { or } 0 \text { otherwise }\end{array}$ \\
\hline External Auditor & This is a dummy variable that is equal to 1 if there are External Auditors or 0 otherwise \\
\hline Health Research & This variable assumes value 1 if the considered NPO has the aim of Health Research or 0 otherwise \\
\hline Multi-Purpose & $\begin{array}{l}\text { This is a dummy variable that is equal to } 1 \text { if the considered NPO has more than one research area or } 0 \\
\text { otherwise }\end{array}$ \\
\hline Scientific Research & This variable assumes value 1 if the considered NPO has the aim of Scientific Research or 0 otherwise \\
\hline Social Balance 2016 & This variable assumes value 1 if the NPO has the availability of the social balance (2016) \\
\hline Volunteering & This variable assumes value 1 if the considered NPO has the aim of Volunteering or 0 otherwise \\
\hline
\end{tabular}

Focus our attention on some variables included in table 2 and 3, the gender role is considered as a number (absolute and percentage) of male and female in the board of directors. Barua et al., (2010) reveal evidence that the presence of females in the board of directors stimulates better performances and less inaccuracies than male only boards. Based on this motivation, as affirmed by Huang et al., (2012) and Huang et al., (2014), we expect a significant role of female in this process.

In addition to these gender variables, some elements are related to the role of governance, control and 
informativeness. In fact, in order to have a complete set of control variables and to verify our hypotheses, according to numerous topical publications (Lo et al., 2010; Nordberg, 2010; Berghe \& Baelden, 2005; Iwasaki, 2008 ) it is important to have information and data related to the different boards of the NPO analyzed. Considering the role of governance and monitoring, each NPO has a precise number of members that are enrolled as board of arbitrators, board of auditors or external auditor. For this motivation, we have measured the different board size and the number of directors in the board (Kohlbeck and Mayhew, 2004; Moscariello, 2011; Nekhili \& Cherif, 2009). This research is aligned, on the same subject that entails a wide number of papers discussing the role of corporate governance and the size of the board (Brick et. al, 2006; De Andres et al., 2005). Considering this factor, there are some papers that affirm that there is a positive relation between the size of the board and the monitoring procedure of the team but, from a literature point of view, related to this point, there are different opinions. On the one hand, if the board is small it is possible that also the control management phases are not efficient (Furlotti et al., 2019; Brick et. al, 2006). On the other hand, Dalton (1999) and Yermack (1996) affirm that a relatively small board can be associated with a good firm performance. From another point of view, big and diversified boards could improve the advice to the CEO and make healthier corporate decisions (Shleifer \& Vishny, 1997; La Porta et al., 1999; Ciftci, et al., 2019; McCahery et al., 2016). For these motivations per Marchini, (2018) there is an evidence on the inconclusive relevance of board size in these analyses.

For this paper, as presented in the previous paragraph, the informativeness has a relevant role and, for this motivation, we have verified the presence of CG information on the official website. Consequently, we are also analyzing the given data adopting an informational and transparent point of view (Capriotti \& Moreno, 2007). To test these two components, we have elaborated an index (CGI index) that include governance and informativeness. It is made by three variables (information into the social balance, information related to the Corporate governance in the social balance and the availability of these information on the official website of the company) and it assume 0 as a minimum value (it means that there are not information related to these fields) or 3 as the maximum value (it means that there are 3 on 3 informativity Corporate Governance elements). In particular, "social Balance" is the generic term to indicate any type of corporate social responsibility report prepared by the NPO. The social balance, if any, has been analyzed to identify corporate governance information provided by the NPO.

From a quantitative point of view, in order to methodologically analyze this data, we have used regression models to test the relations between the $5 * 1000$ amount and the NPO corporate governance information. According to our literature section, the Mechanism of $5 * 1000$, is composed by two fundamental parts: i) the effective choices "scelte espresse"; and ii) the generic choices "scelte generiche".

More specifically, for testing our two hypotheses, the methods of OLS (ordinary least squares multiple regression model) is used. The OLS methods is an optimization technique that consents researchers to find an optimal curve (that is a function) which is as close as possible to the analyzed data. The function minimizes the sum of the squares of the distances between the observed data and those of the curve that represents the function itself (Paruolo, 1999). According to DeFries and Fulker (1985) and Gunst (2018) this methodology is applied in numerous fields, such as business studies (Gazzola et al., 2019b) transportation studies (Grechi \& Maggi, 2018) and cognitive fields (Folgieri et al., 2014). We have elaborated the regression models using Gretl (http://gretl.sourceforge.net/) and R (https://www.r-project.org/).

\section{Results}

In this section, following our two hypotheses are aiming to verify if the extracted data has any direct or indirect relation with the corporate governance variables, or if there are other external elements that potentially interact with the researched ones. Thus, to clarify the results' approach we are adopting a three steps approach.

In the first step, we consider the presentations of three complete regression models for the sample analyzed (Table 4, Full Models). Overall, we are trying to verify the relations between the choices and the entire set of variables.

In the second step, we are considering the two regression models (model 2 and model 3), as exhibited in table 4. Firstly, the results (see Full model 1) are analyzed, using as dependent variable the total amount of $5 * 1000$, which is accumulated by the sum of the amount of the two Italian choices. These are the two aforementioned choices of "scelte generiche" and "scelte espresse". Subsequently, in Full model 2 we adopt the variable Y that represents the generic choices. It represents only the part of amounts of $5 * 1000$, which are distributed with a generic percentage that respects the total percentage amount for the expressed categories.

In the third and final step, we introduce the third full model (see Full model 3) of table 4. In this model the variable $\mathrm{Y}$ is represented by the part of amount chosen, which is the expressed choices. Consequently, in this full 
model 3 we solely consider the part of amounts of $5 * 1000$ that are explicitly destined for a specific NPO. Following is the table 4 :

Table 4. Complete models

\begin{tabular}{|c|c|c|c|c|c|c|}
\hline \multirow{2}{*}{$\begin{array}{l}\text { Model } \\
\text { Independent variable } \\
\text { Variable }\end{array}$} & \multicolumn{2}{|c|}{$\begin{array}{l}\text { Full model } 1 \\
\text { Total choice Amount }\end{array}$} & \multicolumn{2}{|c|}{$\begin{array}{l}\text { Full model } 2 \\
\text { Generic Choices Amount }\end{array}$} & \multicolumn{2}{|c|}{$\begin{array}{l}\text { Full model } 3 \\
\text { Expressed Choices Amount }\end{array}$} \\
\hline & Coefficient Sign & $\operatorname{Pr}(>|t|)$ & Coefficient Sign & $\operatorname{Pr}(>|t|)$ & Coefficient Sign & $\operatorname{Pr}(>|t|)$ \\
\hline Intercept & + & $* * *$ & + & $* * *$ & + & $* * *$ \\
\hline CGI INDEX & + & & + & & + & \\
\hline Volunteering & + & $* * *$ & + & $* *$ & + & $* * *$ \\
\hline Scientific Research & + & $* * *$ & + & $* * *$ & + & $* *$ \\
\hline Health research & + & $* * *$ & + & $* * *$ & + & $* * *$ \\
\hline Board Size & + & $* *$ & + & $* * *$ & + & $* *$ \\
\hline Duality & + & . & + & & + & \\
\hline Male (sex) & - & & - & & - & \\
\hline Corporate Governance and CSR Website & + & $*$ & + & $* *$ & + & $*$ \\
\hline Multi-purpose & - & $* *$ & + & $* * *$ & - & $* *$ \\
\hline Number of Choices & + & $*$ & + & & + & $*$ \\
\hline Members Board & + & & + & & + & \\
\hline Age of the board & - & & - & & - & \\
\hline $\mathrm{R}^{2}$ & 0.39 & & 0.67 & & 0.37 & \\
\hline
\end{tabular}

Signif. codes: 0 ‘***’ 0.001 '**’ 0.01 '*’ 0.05 '? 0.1 ' ’ 1 .

In an effort to further elaborate on our results, we subsequently examine the three restricted models. We are now employing only a selected sample of variables, making some choices related to the relevance of coefficients and the p-values obtained in the complete model, in order to examine if the CGI index has a relation with these amounts (and choices) on our indicated variables, or if there are other hidden control variables which are not considered. The methodological analysis according to the ordinary least squares multiple regression of these three restricted models is presented on table 5,6 and 7 as follows:

Restricted Model 1 (Independent variable: Total Amount)

Table 5. Output regression model 1

\begin{tabular}{llllll}
\hline Estimate & Coefficient & Errore Std. & T value & p-value & Significance \\
\hline const & 55.3968 & 0.2219 & 24.9635 & $<0.0001$ & $* * *$ \\
CGI INDEX & 0.0801 & 0.0557 & 1.4390 & 0.1553 & \\
Board_size & 0.0100 & 0.0044 & 2.2923 & 0.0254 & $* *$ \\
Duality & 0.1323 & 0.1059 & 1.2496 & 0.2163 & \\
Male (sex) & 0.0166 & 0.2472 & 0.0671 & 0.9467 & \\
Corporate Governance and CSR Website & 0.1856 & 0.1045 & 1.7765 & 0.0807 & $*$ \\
Multipurpose & 0.2427 & 0.1248 & 1.9452 & 0.0564 & $*$ \\
\hline
\end{tabular}

Signif. codes: 0 “***’ 0.001 '**’ 0.01 '*’ 0.05 '? 0.1 ' ' 1

Multiple R-squared: 0.22 , Adjusted R-squared: 0.14

F-statistic: 2.82 on 6 and $60 \mathrm{DF}$, p-value: 0.02

Restricted Model 2 (Independent Variable: Generic Choices) 
Table 6. output regression model 2

\begin{tabular}{|c|c|c|c|c|c|c|}
\hline & Estimate & Coefficient & Errore Std. & T value & p-value & Significance \\
\hline & const & 4.640 & 0.285 & 16.275 & $<0.0001$ & $* * *$ \\
\hline & CGI INDEX & -0.0250916 & 0.072 & -0.3506 & 0.7271 & \\
\hline & Board_size & 0.011 & 0.006 & 1.939 & 0.0572 & * \\
\hline & Duality & -0.110201 & 0.136 & -0.8093 & 0.4215 & \\
\hline & Male (sex) & 0.162 & 0.318 & 0.511 & 0.6114 & \\
\hline & Corporate Governance and CSR Website & 0.198 & 0.134 & 1.473 & 0.146 & \\
\hline & Multipurpose & 0.690 & 0.160 & 4.303 & $<0.0001$ & $* * *$ \\
\hline \multicolumn{7}{|c|}{ Signif. codes: 0 “***’ 0.001 ‘**’ 0.01 “*’ 0.05 ‘' 0.1 ' ’ 1} \\
\hline \multicolumn{7}{|c|}{ Multiple R-squared: 0.37, Adjusted R-squared: 0.28} \\
\hline statistic: 4.57 & 6 and $60 \mathrm{DF}$, p-value: 0.0001 & & & & & \\
\hline
\end{tabular}

Restricted Model 3 (Independent Variable: Expressed Choices)

Table 57. output model 3

\begin{tabular}{|c|c|c|c|c|c|c|}
\hline & Estimate & Coefficient & Errore Std. & T value & p-value & Significance \\
\hline & const & 5.430 & 0.217 & 25.080 & $<0.0001$ & $* * *$ \\
\hline & CGI INDEX & 0.101 & 0.054 & 1.850 & 0.0683 & $*$ \\
\hline & Board_size & 0.010 & 0.004 & 2.400 & 0.0193 & $* *$ \\
\hline & Duality & 0.181 & 0.103 & 1.750 & 0.0846 & $*$ \\
\hline & Male (sex) & -0.0108726 & 0.241 & -0.040 & 0.9642 & \\
\hline & Corporate Governance and CSR Website & 0.184 & 0.102 & 1.800 & 0.0767 & $*$ \\
\hline & Multipurpose & 0.176 & 0.122 & 1.440 & 0.1529 & \\
\hline \multicolumn{7}{|c|}{ Signif. codes: 0 ‘***' 0.001 '**’ 0.01 '*' 0.05 '. 0.1 ' ' 1} \\
\hline \multicolumn{7}{|c|}{ Multiple R-squared: 0.23 , Adjusted R-squared: 0.16} \\
\hline statistic: 3.1 & 6 and $60 \mathrm{DF}$, p-value: 0.01 & & & & & \\
\hline
\end{tabular}

The above analysis concludes the exhibition of the three full models' results. Therefore, according to our principal aim of our work the above result-tables are contributing to a better understanding of a dynamic relation which could be statistically significant, between the $5 * 1000$ amount and the corporate governance index. The results, which are sourced from the official data of the Italian revenue agency relating to the NPO sector, are discussed in the following conclusion section.

\section{Discussion and Conclusion}

Overall, the results of this study are not confirming a direct relationship between the indicated variables and the CGIindex (note 2). In fact, even when we are employing the complete set of variables, it seems that there is no relation between the transparency of the corporate governance and the money amount related to the top 100 NPO sample. Therefore, in order to further test our two hypotheses, three restricted regression models (restricted model 1, 2, 3) are calculated, after excluding some control variables, evaluating the relations emerged in the full models and the significances. Such an approach allows us to further verify the taxpayer's attention to the information component linked to the concepts of corporate governance.

In full model 1, where the $\mathrm{Y}$ variable is denoted by the total choice amount, it is possible to conclude that there is a positive and strong significance for the three research areas. Considering the multipurpose variable, this significance is negative for the models related to the total amount of the 5 per thousand and the expressed choices, while it is positive for the generic choices. The corporate governance and CSR website variable indicates a positive element, and the number of choices it seems to be significant only for the full model's total amount (see restricted model 1 on table 5). In addition, considering also full model 2 and 3 the board size variable is positive and statistically significant for all the three models. It demonstrates the fact that larger boards generate greater trust in stakeholders, and particularly in donors, as the corporate diversity parameter provides a valuable input. These relevancies are sustained from numerous authors, such as Carter et. al (2003) that found a positive relationships between the of women or on the board and the value of the firm. Moreover, regarding the multipurpose variable, in the three full models, it is possible to underline that there is always a strict statistically significance, but with different signs. In fact, the coefficient is positive for generic choices and negative for all 
the others. Therefore, in relation to the number of choices, this very interesting finding reveals a clear direction. The finding concerns the fact that the taxpayers are mainly interested in selecting NPOs that have a clear line of research, ignoring the multi-purpose NPOs.

Considering the restricted models, and focus the attention on the restricted model 1, that has the total amount as an independent variable, it shows that there is a positive relation and statistically significant, for multi-purpose, corporate governance and CSR website and board size. As a result, corporate and social diversity factors should be considered in future research, as it seems that the CGI index is not an explanatory variable of the Total $5^{*} 1000$ amount. Overall, we replicated the analysis using generic choices and expressed choices to verify if there is any statistical significance or if there is any correlation between donations and the promotion of the corporate governance through official documents, informativeness of the websites and social balance.

In restricted model 2, where the $\mathrm{Y}$ variable is represented by the generic choices, it is possible to conclude that there is some positive significance relating to the multipurpose and the size of the board. We also notice that the CGI index is negative and not statistically significant. This last finding reveals that the centralized distribution mechanism is not explicit towards these informative dimensions, ignoring valuable soft skills, including the social ones. Although, it is clearly linked with the mechanism for assigning these generic quotas of $5 * 1000$, which has no connection with the information component. As a result, if the user has not indicated any tax code for the purpose of $5 * 1000$ allocation, the corresponding donation-sums are proportionally distributed within the same NPO purpose-category, according to the total number of NPO destinations. The donation distribution is implemented according to the indicated tax code, as obtained by each of the subjects present in the lists. As a result, hypothesis $\mathrm{H} 1$ is partially accepted. Given the accumulated sample results, the generic choice amount is not exhibiting any positive relation to the information component.

In model 3, where the $\mathrm{Y}$ variable is represented by the expressed choices, we recognize an interesting picture. In fact, we are able to detect different results from the ones found in model 1 and 2. Therefore, the CGI index is statistically significant and positive. The result indicates that the choices expressed are influenced by the information contained in this choice. Furthermore, the variables: i) board size; ii) duality; and iii) corporate governance and CSR website; are also significant and positive. Donors show that they appreciate this information: the website therefore becomes an important information tool. A different element, in respect to the other two models (models 1 and 2), is the non-significance of the multipurpose element. This finding is interesting because it seems that the expressed $5 * 1000$ quote is not directly related with NPOs indicating more than one research area.

Combining the results we are able to identify a clear corporate governance picture where taxpayers seem to possess an incentive to ensure that their $5 * 1000$ choices. This incentive is directly related with a high level of information exhibited for the selected NPO in the selected category. The role of the following variables: i) extensive profile-information; ii) usability of the website; and iii) activity information seem to be of prominent importance for the transparency element of the NPO. Therefore, transparency is one of the CG elements that clearly influence the users towards their donations. Consequently, hypothesis $\mathrm{H} 2$ is accepted, as the user is more inclined to allocate $5 * 1000$ to organizations where the information level, from a governance point of view, is high and there is a clear purpose for the specified field of research.

In conclusion, the formative role of the NPO is quite relevant and important in the aforementioned context. From the analysis carried out, it is clear that the Italian taxpayers explore the destination choices for the $5 * 1000$, favoring NPO with a clear univocal research direction. Based on our data analysis, this fact is widely undermined from current practices, and should to be further researched. Moreover, the CGI index seems to have a statistically significant relation with the multi-purpose NPO. Finally, given the present data, it is affirmed that there is no clear relationship among the informativeness, the accessibility of the CG information and the decisions of the bodies responsible for the division of $5 * 1000$ for generic choices. It is noticeable that taxpayers examine the transparency variables provided by the information availability of the NPO's digital profile, the NPO's webpage presence, and finally the exhibited NPO's social activities. Overall, our research reveals that corporate practices in Italy are becoming more sensitive to corporate governance principles, as they are becoming meticulous not only to the hard but also to the soft skills of the managerial resources employed.

\section{Limitations}

This research has certain limitations. A main research limitation relates to the data availability. The selected sample is referred only to 2016 and for this reason the results could be considered as partially outdated. The research, in fact, focuses on the year 2016, which is a critical year before the Third Sector Reform and therefore worthy of attention. A possible future step of this research will certainly be a database integration containing also 
data from 2017 and 2018, thus trying to understand what has changed since the aforementioned reform. Further integration will allow us to expand the sample and evaluate if the assumptions and hypotheses remain consistent. In addition, future research could consider other elements that could influence the capacity of an NPO of collecting donations (such as notoriety and advertising spending) and also could conduct the same analysis referring to other Countries in order to pre-assess the possibility of extending the findings to other areas and, consequently, to make international comparisons.

\section{References}

Ahn, S., \& Walker, M. D. (2007). Corporate governance and the spinoff decision. Journal of Corporate Finance, 13(1), 76-93. https://doi.org/10.1016/j.jcorpfin.2006.03.001

Airoldi, G., Brunetti, G., \& Coda, V. (2005). Corso di economia aziendale. Bologna: Il mulino.

Anheier, H. K. (2005). Nonprofit Organisations: Theory, Management, Policy. London: Routledge.

Banding, M. P., \& Mayangsari, S. (2017). The Impact of Financial and Non-Financial Information Disclosure to Donation Decision in NonProfit Organization by Individual Donor (A True-Experiment Research). Financial Accounting, 8(16), 9-19.

Barua, A., Davidson, L. F., Rama, D. V., \& Thiruvadi, S. (2010). CFO gender and accruals quality. Accounting Horizons, 24(1), 25-39. https://doi.org/10.2308/acch.2010.24.1.25

Bauguess, S. W., Moeller, S. B., Schlingemann, F. P., \& Zutter, C. J. (2009). Ownership structure and target returns. Journal of Corporate Finance, 15(1), 48-65. https://doi.org/10.1016/j.jcorpfin.2008.09.002

Bellante, G., Berardi, L., Machold, S., Nissi, E., \& Rea, M. A. (2018). Accountability, governance and performance in UK charities. International Journal of Business Performance Management, 19(1), 55-74. https://doi.org/10.1504/IJBPM.2018.088493

Bendickson, J., Muldoon, J., Liguori, E., \& Davis, P. E. (2016). Agency theory: the times, they are a-changin. Management Decision, 54(1), 174-193. https://doi.org/10.1108/MD-02-2015-0058

Bernstein, R. S., Buse, K., \& Slatten, L. A. (2015). Nonprofit board performance: Board members' understanding their roles and responsibilities. American Journal of Management, 15(1), 24-35.

Berkman, H., Cole, R. A., \& Fu, L. J. (2009). Expropriation through loan guarantees to related parties: Evidence from China. Journal of Banking \& Finance, 33(1), 141-156. https://doi.org/10.1016/j.jbankfin.2007.11.001

Bhagat, S., \& Black, B. (2001). The non-correlation between board independence and long-term firm performance. J. CorP. l., 27, 231.

Bhagat, S., \& Bolton, B. (2008). Corporate governance and firm performance. Journal of Corporate Finance, 14(3), 257-273. https://doi.org/10.1016/j.jcorpfin.2008.03.006

Brav, A., Graham, J. R., Harvey, C. R., \& Michaely, R. (2005). Payout policy in the 21st century. Journal of Financial Economics, 77(3), 483-527. https://doi.org/10.1016/j.jfineco.2004.07.004

Brick, I. E., Palmon, O., \& Wald, J. K. (2006). CEO compensation, director compensation, and firm performance: Evidence of cronyism? Journal of Corporate Finance, 12(3), 403-423. https://doi.org/10.1016/j.jcorpfin.2005.08.005

Bureau, V. D. (2012). Banca dati analisi informatizzata delle aziende, Roma.

Capriotti, P., \& Moreno, A. (2007). Corporate citizenship and public relations: The importance and interactivity of social responsibility issues on corporate websites. Public Relations Review, 33(1), 84-91. https://doi.org/10.1016/j.pubrev.2006.11.012

Carter, D. A., Simkins, B. J., \& Simpson, W. G. (2003). Corporate governance, board diversity, and firm value. Financial Review, 38(1), 33-53. https://doi.org/10.1111/1540-6288.00034

Castellani, D., Serti, F., \& Tomasi, C. (2010). Firms in international trade: Importers' and exporters' heterogeneity in Italian manufacturing industry. World Economy, 33(3), 424-457. https://doi.org/10.1111/j.1467-9701.2010.01262.x

Chakraborty, A., Gao, L., \& Sheikh, S. (2019). Corporate governance and risk in cross-listed and Canadian only companies. Management Decision, 57(10), 2740-2757. https://doi.org/10.1108/MD-10-2017-1052

Chan, H., Faff, R. W., Khan, A., \& Mather, P. R. (2013). Exploring the moderating role of growth options on the relation between board characteristics and management earnings forecasts. Corporate Governance: An 
International Review, 21(4), 314-333. https://dx.doi.org/10.1111/corg.12027

Chen, G., Firth, M., Gao, D. N., \& Rui, O. M. (2006). Ownership structure, corporate governance, and fraud: Evidence from China. Journal of Corporate Finance, 12(3), 424-448. https://doi.org/10.1016/j.jcorpfin.2005.09.002

Chen, K. C., Chen, Z., \& Wei, K. J. (2009). Legal protection of investors, corporate governance, and the cost of equity capital. Journal of Corporate Finance, 15(3), 273-289. https://doi.org/10.1016/j.jcorpfin.2009.01.001

Chidambaran, N. K., \& Prabhala, N. R. (2003). Executive stock option repricing, internal governance mechanisms, and management turnover. Journal of Financial Economics, 69(1), 153-189. https://doi.org/10.1016/S0304-405X(03)00111-9

Chokkalingam, T. (2017). Effect of Charitable Giving: Donors' Choice of Governance. Advances in Social Sciences Research Journal, 4(11), 1-13. https://doi.org/10.14738/assrj.411.3238

Choi, B. B., Lee, D., \& Park, Y. (2013). Corporate Social Responsibility, Corporate Governance and Earnings Quality: Evidence from Korea. Corporate Governance: An International Review, 21(5), 447-467. https://doi.org/10.1111/corg. 12033

Chung, R., Firth, M., \& Kim, J. B. (2002). Institutional monitoring and opportunistic earnings management. Journal of corporate finance, 8(1), 29-48. https://doi.org/10.1016/S0929-1199(01)00039-6

Ciftci, I., Tatoglu, E., Wood, G., Demirbag, M., \& Zaim, S. (2019). Corporate governance and firm performance in emerging markets: Evidence from Turkey. International Business Review, 28(1), 90-103. https://doi.org/10.1016/j.ibusrev.2018.08.004

Dalton, D. R., Daily, C. M., Johnson, J. L., \& Ellstrand, A. E. (1999). Number of directors and financial performance: A meta-analysis. Academy of Management journal, 42(6), 674-686. https://doi.org/10.5465/256988

De Andres, P., Azofra, V., \& Lopez, F. (2005). Corporate boards in OECD countries: Size, composition, functioning and effectiveness. Corporate Governance: An International Review, 13(2), 197-210. https://doi.org/10.1111/j.1467-8683.2005.00418.x

DeFries, J. C., \& Fulker, D. W. (1985). Multiple regression analysis of twin data. Behavior genetics, 15(5), 467-473. https://doi.org/10.1007/BF01066239

Denis, D. J., Denis, D. K., \& Sarin, A. (1997). Agency problems, equity ownership, and corporate diversification. The Journal of Finance, 52(1), 135-160. https://doi.org/10.1111/j.1540-6261.1997.tb03811.x

Denis, D. K., \& McConnell, J. J. (2003). International corporate governance. Journal of financial and quantitative analysis, 38(1), 1-36. https://doi.org/10.2307/4126762

Eldenburg, L., Hermalin, B. E., Weisbach, M. S., \& Wosinska, M. (2001). Hospital governance, performance objectives, and organizational form (No. w8201). National Bureau of Economic Research. https://doi.org/10.3386/w8201

Folgieri, R., Lucchiari, C., Granato, M., \& Grechi, D. (2014). Brain, technology and creativity. BrainArt: A BCI-based entertainment tool to enact creativity and create drawing from cerebral rhythms. In Digital Da Vinci (pp. 65-97). Springer, New York, NY.

Freeman, R. E. (1984). Strategic Management: A Stokcholder Approach. Pitman.

Furlotti, K., Mazza, T., Tibiletti, V., \& Triani, S. (2019). Women in top positions on boards of directors: Gender policies disclosed in Italian sustainability reporting. Corporate Social Responsibility and Environmental Management, 26(1), 57-70. https://doi.org/10.1002/csr.1657

Gandía, J. L. (2008). Determinants of internet-based corporate governance disclosure by Spanish listed companies. Online Information Review, 32(6), 791-817. https://doi.org/10.1108/14684520810923944

Gazzola, P., \& Amelio, S. (2015). The value of human resources in non profit organizations. The Italian situation. Economia Aziendale Online, 6(1), 1-9. http://dx.doi.org/10.6092/2038-5498/6.1.1-9

Gazzola, P., Amelio, S., Papagiannis, F., \& Michaelides, Z. (2019a). Sustainability reporting practices and their social impact to NGO funding in Italy. Critical Perspectives on Accounting, https://doi.org/10.1016/j.cpa.2019.04.006

Gazzola, P., Grechi, D., Ossola, P., \& Pavione, E. (2019b). Certified Benefit Corporations as a new way to make sustainable business: The Italian example. Corporate Social Responsibility and Environmental Management, 
26(6), 1435-1445. https://doi.org/10.1002/csr.1758

Gazzola, P., Ratti, M., \& Amelio, S. (2017). CSR and sustainability report for nonprofit organizations. An Italian best practice. Management Dynamics in the Knowledge Economy, 5(3), 355-376.

Grechi, D., \& Maggi, E. (2018). The importance of punctuality in rail transport service: an empirical investigation on the delay determinants. European Transport-Trasporti Europei, 70, 1-23.

Gretl software: http://gretl.sourceforge.net

Grossman, S. J., \& Hart, O. D. (1986). The costs and benefits of ownership: A theory of vertical and lateral integration. Journal of Political Economy, 94(4), 691-719. https://doi.org/10.1086/261404

Gunst, R. F. (2018). Regression analysis and its application: a data-oriented approach. Abingdon on Thames: Routledge.

Hart, O., \& Moore, J. (1990). Property Rights and the Nature of the Firm. Journal of political economy, 98(6), 1119-1158. https://doi.org/10.1086/261729

Hasnan, S., Mohamad, M., Zainuddin, Z. N., \& Abidin, Z. Z. (2016). Corporate governance factors affecting donation: Evidence from charitable organizations in Malaysia. International Journal of Economics and Financial Issues, 6(6S).

Herlin, H., \& Pazirandeh, A. (2012). Nonprofit organizations shaping the market of supplies. International Journal of Production Economics, 139(2), 411-421. https://doi.org/10.1016/j.ijpe.2011.04.003

Hess, T.M., \& Auman, C. (2001). Aging and social expertise: the impact of trait- diagnostic information on impressions of others. Psychology and Aging, 16(3), 497-510. https://doi.org/10.1037/0882-7974.16.3.497

Hewitt, J. A., \& Brown, D. K. (2000). Agency costs in environmental not-for-profits. Public Choice, 103(1-2), 163-183. https://doi.org/10.1023/A:1005092819278

Hideto Dato, M., Hudon, M., \& Mersland, R. (2020). Board Governance: Does Ownership Matter? Annals of Public and Cooperative Economics, 91(1), 5-28. https://doi.org/10.1111/apce.12262

Hu, S. H., Li, G., Xu, Y. H., \& Fan, X. A. (2012). Effects of internal governance factors on cross-border-related party transactions of Chinese companies. Emerging Markets Finance and Trade, 48(sup1), 58-73. https://doi.org/10.2753/REE1540-496X4801S105

Huang, H. W., Rose-Green, E., \& Lee, C. C. (2012). CEO age and financial reporting quality. Accounting Horizons, 26(4), 725-740. https://doi.org/10.2308/acch-50268

Huang, T. C., Huang, H. W., \& Lee, C. C. (2014). Corporate executive's gender and audit fees. Managerial Auditing Journal, 21(6), 527-547 https://doi.org/10.1108/MAJ-03-2013-0837

Iwasaki, I. (2008). The determinants of board composition in a transforming economy: Evidence from Russia. Journal of Corporate Finance, 14(5), 532-549. https://doi.org/10.1016/j.jcorpfin.2008.09.005

Jegers, M. (2009). "Corporate" governance in nonprofit organizations: A nontechnical review of the economic literature. Nonprofit Management and Leadership, 20(2), 143-164. https://doi.org/10.1002/nml.246

Jensen, M. C., \& Meckling, W. H. (1979). Theory of the firm: Managerial behavior, agency costs, and ownership structure. In Economics social institutions (pp. 163-231). Springer, Dordrecht.

Koh, S., Durand, R. B., Dai, L., \& Chang, M. (2015). Financial distress: Lifecycle and corporate restructuring. Journal of Corporate Finance, 33, 19-33. https://doi.org/10.1016/j.jcorpfin.2015.04.004

Kohlbeck, M. J., \& Mayhew, B. W. (2004, September). Related party transactions. In AAA 2005 FARS Meeting Paper.

La Porta, R., Lopez-de-Silanes, F., \& Shleifer, A. (1999). Corporate ownership around the world. The journal of finance, 54(2), 471-517. https://doi.org/10.1111/0022-1082.00115

Liu, Q., \& Lu, Z. J. (2007). Corporate governance and earnings management in the Chinese listed companies: A tunneling perspective. Journal of Corporate Finance, 13(5), 881-906. https://doi.org/10.1016/j.jcorpfin.2007.07.003

Lo, A. W., Wong, R. M., \& Firth, M. (2010). Can corporate governance deter management from manipulating earnings? Evidence from related-party sales transactions in China. Journal of Corporate Finance, 16(2), 225-235. https://doi.org/10.1016/j.jcorpfin.2009.11.002

Marchini, P. L., Mazza, T., \& Medioli, A. (2018). Related party transactions, corporate governance and earnings 
management. Corporate Governance: The International Journal of Business in Society, 18(6), 1124-1146. https://doi.org/10.1108/CG-11-2017-0271

McCahery, J. A., Sautner, Z., \& Starks, L. T. (2016). Behind the scenes: The corporate governance preferences of institutional investors. The Journal of Finance, 71(6), 2905-2932. https://doi.org/10.1111/jofi.12393

Miller-Millesen, J. L. (2003). Understanding the behavior of nonprofit boards of directors: A theory-based approach. Nonprofit and Voluntary Sector Quarterly, 32(4), 521-547. https://doi.org/10.1177\%2F0899764003257463

Moore, M., \& Stewart, S. (1998). Corporate governance for NGOs? Development in Practice, 8(3), 335-342. https://doi.org/10.1080/09614529853620

Moscariello, N. (2012). Related party transactions in continental European countries: Evidence from Italy. International Journal of Disclosure and Governance, 9(2), 126-147. https://doi.org/10.1057/jdg.2011.14

Murro, P., \& Peruzzi, V. (2018). Cooperative banks and income inequality: Evidence from Italian provinces (No. 481). ECINEQ, Society for the Study of Economic Inequality.

Nekhili, M., \& Cherif, M. (2009). Transactions avec les parties liées, caractéristiques de propriété et de gouvernance et performance des entreprises françaises. Comptabilité-Contrôle-Audit, 15(3), 55-89. https://doi.org/10.3917/cca.153.0055

Netter, J., Poulsen, A., \& Stegemoller, M. (2009). The rise of corporate governance in corporate control research. Journal of Corporate Finance, 15(1), 1-9. https://doi.org/10.1016/j.jcorpfin.2008.10.002

Nordberg, D. (2010). Corporate governance: Principles and issues. New York: Sage.

Ostrower, F., \& Stone, M. M. (2006). Governance: Research trends, gaps, and future prospects. In The nonprofit sector: A research handbook (pp. 612-628). Yale: Yale University Press.

Park, Y. W., \& Shin, H. H. (2004). Board composition and earnings management in Canada. Journal of corporate Finance, 10(3), 431-457. https://doi.org/10.1016/S0929-1199(03)00025-7

Paruolo, P. (1999). Elementi di statistica. Bologna: Carocci.

Peng, H. (2019), Organizational ambidexterity in public non-profit organizations: interest and limits, Management Decision, Vol. 57 No. 1, pp. 248-261. https://doi.org/10.1108/MD-01-2017-0086

Radinger, G. (2017). My taxes go to NGOs! Centre for Philanthropy. Vienna: ERSTE Foundation.

Randøy, T., \& Nielsen, J. (2002). Company performance, corporate governance, and CEO compensation in Norway and Sweden. Journal of Management and Governance, 6(1), 57-81. https://doi.org/10.1023/A:1015511912289

Salamon, L. M., \& Anheier, H. K. (1997). Defining the nonprofit sector: A cross-national analysis. Manchester: Manchester University Press.

Shapira, Z. (2000). Governance in organizations: A cognitive perspective. Journal of Management and Governance, 4(1-2), 53-67. https://doi.org/10.1023/A:1009945503527

Shleifer, A., \& Vishny, R. W. (1997). A survey of corporate governance. The journal of finance, 52(2), 737-783. https://doi.org/10.1111/j.1540-6261.1997.tb04820.x

Speckbacher, G. (2008). Nonprofit versus corporate governance: An economic approach. Nonprofit management and leadership, 18(3), 295-320. https://doi.org/10.1002/nml.187

Steinberg, R. (2003). Economic theories of nonprofit organizations. In The study of the nonprofit enterprise (pp. 277-309), Boston, MA: Springer

Sundaram, R. K., \& Yermack, D. L. (2007). Pay me later: Inside debt and its role in managerial compensation. The Journal of Finance, 62(4), 1551-1588. https://doi.org/10.1111/j.1540-6261.2007.01251.x

Tirole, J. (2001). Corporate Governance. Econometrica, 69, 1-15.

Turley, S., \& Zaman, M. (2004). The corporate governance effects of audit committees. Journal of management and governance, 8(3), 305-332. https://doi.org/10.1007/s10997-004-1110-5

Van den Berg, A. (2004). The contribution of work representation to solving the governance structure problem. Journal of Management and Governance, 8(2), 129-148. https://doi.org/10.1023/B:MAGO.0000026541.89732.c2 
Van den Berghe, L. A., \& Baelden, T. (2005). The monitoring role of the board: one approach does not fit all. Corporate Governance: An International Review, 13(5), 680-690. https://doi.org/10.1111/j.1467-8683.2005.00459.x

Williamson, O. E. (1985). The Economic Institutions of Capitalism. New York: Free Press.

Yeo, A. C., Chong, C. Y., \& Carter, S. (2017). Governance practices and disclosure by not-for-profit organizations: effect on the individual donating decision. In Empowering 21st Century Learners Through Holistic and Enterprising Learning (pp. 243-254). Springer, Singapore.

Yermack, D. (1996). Higher market valuation of companies with a small board of directors. Journal of financial economics, 40(2), 185-211.

Yim, S. (2013). The acquisitiveness of youth: CEO age and acquisition behavior. Journal of Financial Economics, 108(1), 250-273. https://doi.org/10.1016/j.jfineco.2012.11.003

\section{Notes}

Note 1. 18 NPO on 100 have declared more than one research area, for this motivation, to make more feasible the sample, we have highlighted this concept in the coloumn Multi-Purpose.

Note 2. In addition, some variables (Executive_Committee and Auditors_Board) have been omitted at this stage due to lack of information.

\section{Copyrights}

Copyright for this article is retained by the author(s), with first publication rights granted to the journal.

This is an open-access article distributed under the terms and conditions of the Creative Commons Attribution license (http://creativecommons.org/licenses/by/4.0/). 